\title{
One Step Closer To European Union: Smart Card Technology In Turkey
}

James Lawler, (Email: Lawlerj@aol.com), Pace University

Deniz Erdem-Arslan, (Email: de71944n@pace.edu), Pace University

\begin{abstract}
Europe and Asia are competing to deploy smart cards for functions from banking to retailing to telecommunications. This study analyzes factors that contribute to the implementation of smart card technology, focusing on smart card and magnetic card technologies in the financial industry in Turkey. The paper examines the effects of technological and business factors on Turkish banks, such as Akbank, Deniz Bank, Garanti Bankasi, and Tekstil Bank. The business factors are budgeting, culture, customization, and loyalty, and the technical factors are infrastructure, multi-functionality, payment speed, and transaction security. This exploratory study will assist international and local entrepreneurial entrants to the financial industry in Turkey, in taking advantage of smart card technology.
\end{abstract}

\section{BACKGROUND}

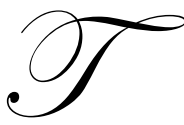

he smart card is a credit card sized device and intelligent token that includes an integrated circuit chip. The card furnishes both memory capacity and computational capability. This self-containment of the smart card enables it to be resistant to intrusion, as it does not need to depend upon potentially vulnerable external resources. Because of this characteristic, smart cards are often used in diverse applications that require strong security protection and authentication (Chan, 1999).

Having single-factor authentication, such as a password, is a significant security risk. A single password can be compromised. Strong authentication requires a few considerations. Smart cards function with other authentication techniques by storing combinations of password files, public key infrastructure (PKI) certificates, one-time password seed files, or bio-metric image templates on a single card (Alliance, 2004). For this purpose, some organizations, such as the municipality of Oceanside, California, in the United States, deploys a bio-metric system for its information technologists that requires fingerprint access (Gilhooly, 2001).

Global card manufacturing revenue increased $27.1 \%$ to $\$ 6.1$ billion in 2003 , indicating the growing implementation of smart cards in banking and mobile telephones, according to the annual survey of the International Card Manufacturers Association. Unit sales increased 9.3\% to 11.7 billion cards. While chip cards represented only $16.2 \%$ of units shipped, they accounted for $78.7 \%$ of dollar volume because of their higher cost. Smart card shipments increased $6.3 \%$ to 1.9 billion cards, while the dollar value of smart cards shipped increased to $\$ 4.8$ billion. North America accounted for $53.1 \%$ of the units, but was fourth among the major regions of the world, due to relatively slow growth of smart cards. Europe was first in dollar volume and second in units shipped with $22.1 \%$. Asia/Pacific was third in units shipped with $17.8 \%$ of the global total, boosted by strong growth in China (Thomson, 2004).

Further information on the production of microprocessor units is listed in Table 1 (Alliance, 2003). 
Table 1: Microprocessor Card Production

(Cards in Million Units)

\begin{tabular}{|l|c|c|c|c|c|c|c|}
\hline \multicolumn{3}{|c|}{ Market } & \multicolumn{4}{c|}{ Region } \\
\hline & Banking & Mobile & Other & $\begin{array}{c}\text { Europe/ } \\
\text { Middle East } \\
\text { /Africa }\end{array}$ & $\begin{array}{c}\text { Asia / } \\
\text { Pacific }\end{array}$ & $\begin{array}{c}\text { South } \\
\text { America }\end{array}$ & $\begin{array}{c}\text { North } \\
\text { America }\end{array}$ \\
\hline $\mathbf{2 0 0 1}$ & 145 & 400 & 97 & 230 & 272 & 20 & 30 \\
\hline $\mathbf{2 0 0 2}$ & 170 & 450 & 105 & 340 & 310 & 25 & 50 \\
\hline $\mathbf{2 0 0 3}$ & 190 & 480 & 134 & 360 & 350 & 34 & 60 \\
\hline $\mathbf{2 0 0 4}$ & 230 & 530 & 170 & 385 & 425 & 45 & 75 \\
\hline
\end{tabular}

The importance of smart card technology is in its advantages. These include flexibility, reliability, and higher storage capacity than current magnetic strip cards. Encryption of information and tamper-resistant storage for protecting private keys and other forms of personal information are advantages. Isolated security critical computations, including authentication, digital signature and key exchange from other parts of the system, and portability of credentials and other private information between computers at home, office, or on the road are further advantages (Petersburg et. al., 2002).

Other advantages are furnishing a high level of security both in terms of authenticating the card and ascertaining the cardholder. The technology supports multiple applications, resulting in cost savings and potential revenue streams. It functions securely in industries where on-line communication is either not feasible or not cost effective, such as in numerous pre-paid applications. It further functions in locations where on-line systems are unreliable. The technology is recognized as the next generation financial transaction card (Townsend, 2003).

The enhanced security is not the only explanation as to why smart cards are becoming the preferred method for logical access. Smart cards create enhanced user convenience through their broad application coverage, ease of integration with information technology infrastructure, and multi-functionality. Currently, customers have in their wallets an average of 10 plastic cards, magnetic stripes and pins furnishing diverse facilities (Smart Card Group, 2002). The microprocessor chip that is credited for the intelligence in smart cards offers greater capacity and security than was ever available with magnetic stripes.

\section{INTRODUCTION}

Turkey is currently recovering from a severe economic contraction in 2001. Following years of consistent economic growth of $3.7 \%$ annually from 1991 to 2000, with a decline in 1999 due to severe earthquakes, the economic condition of the country deteriorated in February 2001, as a devastating financial crisis forced the country to sharply devalue its currency, the lira. Also, inflation and unemployment increased in the country, and gross domestic product (GDP) decreased $7.4 \%$ in 2001. This crisis was exacerbated partially by structural issues, such as political instability, in conjunction with issues in the financial industry in Turkey. The September 2001 terrorism in the United States further exacerbated issues in Turkey, with the International Monetary Fund (IMF) indicating "lower export demand, loss of tourism receipts, reduced access to international financial markets, and reduced privatization and foreign direct investment prospects" (Feld, 2004).

In 2004 Turkey continued economic recovery from the economic crisis in 2001. Based on estimates from Yapi Kredi Bankasi, GDP is forecasted to increase by 9\% in 2004, following above average growth in 2003 and 2002. High growth in exports and increased consumption and investment demand in the private sector led to increased growth in the industrial sector. Services sector growth further increased in Turkey, due to increased activity in the trade, transportation and tourism sectors. (Yapi Kredi Bankasi, 2004). The expected formal relationship with the European Union and the International Monetary Fund in 2005 favored recovery in 2004.

Further information illustrating economic recovery in Turkey is listed in Table 2 (Yapi Kredi Bankasi, 2004): 
Table 2: Economy in Turkey

(November 2004)

GNP

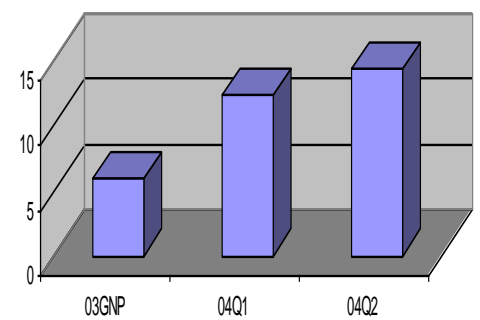

GDP

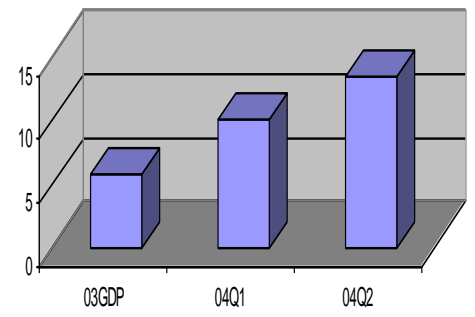

In 2004 GDP in Turkey is forecasted to increase $4.2 \%$, following $7.9 \%$ in 2002 and $5.8 \%$ in 2003, with $11.6 \%$ inflation (Feld, 2004).

In 2004 the number of banks decreased slightly in the financial industry in Turkey.

Further information indicating the number of banks in Turkey is listed in Table 3 (Turkish Bank Association, 2004):

Table 3: Financial Industry in Turkey

December 2003 - September 2004

\begin{tabular}{|l|c|c|c|c|c|c|}
\hline & \multicolumn{2}{|c|}{ December 2003 } & \multicolumn{2}{|c|}{ June 2004 } & \multicolumn{2}{c|}{ September 2004 } \\
\hline & Banks & Branches & Banks & Branches & Banks & Branches \\
\hline Commercial Banks & $\mathbf{3 6}$ & $\mathbf{5 , 9 4 9}$ & $\mathbf{3 5}$ & $\mathbf{5 , 9 9 5}$ & $\mathbf{3 5}$ & $\mathbf{6 , 0 3 1}$ \\
\hline State Owned Banks & 3 & 1,971 & 3 & 1,958 & 3 & 1,957 \\
\hline Privately Owned Banks & 18 & 3,594 & 18 & 3,654 & 18 & 3,692 \\
\hline Banks in Deposit Insurance Fund & 2 & 175 & 2 & 175 & 2 & 174 \\
\hline Foreign Banks & 13 & 209 & 12 & 208 & 12 & 208 \\
\hline Non-Depository Banks & $\mathbf{1 4}$ & $\mathbf{1 7}$ & $\mathbf{1 4}$ & $\mathbf{1 9}$ & $\mathbf{1 4}$ & $\mathbf{1 9}$ \\
\hline Total & $\mathbf{5 0}$ & $\mathbf{5 , 9 6 6}$ & $\mathbf{4 9}$ & $\mathbf{6 , 0 1 4}$ & $\mathbf{4 9}$ & $\mathbf{6 , 0 5 0}$ \\
\hline
\end{tabular}

The number of branches increased to 6,050 from 5,966, and those of privately owned banks increased noticeably from 3,594 to 3,692 , in 2004 . The number of branches in state owned commercial banks decreased from 1,971 to 1,957 , while the number of foreign banks and those in the deposit insurance fund decreased from 209 to 208 and from 175 to 174, in 2004. There were 652 branches per bank in state owned commercial banks and 205 branches in privately owned commercial banks, and there were 17 branches per foreign bank, in 2004.

In 1995 Visa co-developed EMV (EuroPay, MasterCard and Visa) industry chip card specifications that defined new standards for the payment card market developed by EMV. The intent is to ensure that chip cards will be compatible with chip reading terminals, regardless of financial institution, location, or manufacturer. This has ensured that smart credit cards and debit cards are standardized so that cardholders can confidently access their accounts with their chips cards from international EMV terminals (USA Visa, 2004). 
Smart cards offer the financial industry in other countries and in Turkey a clear option to enhance security and curb the disturbingly high rate of fraud associated with magnetic stripe cards. Increased demand due to EMV migration deadlines and industry pressure are compelling institutions to introduce smart cards (Alto, 2004).

Turkey is concurrently developing its economy to respond to the pressures of the European single market. Its determination to improve its relationship with the European Union has had its banking industry representatives focusing increased emphasis on ensuring that industry processes and regulations are in harmony with those of the Union. Turkey has already accepted European Union practices on capital adequacy.

Gemplus International, the leading firm in smart card solutions, announced the initiation of a strategic partnership for the local production of smart cards with a fully Turkish owned manufacturer of smart cards in 2003. The agreement aims to deliver Gemplus card technology to the Turkish market through flexible local production facilities. Amid the mounting pressure to comply with new EMV standards that specify that magnetic stripe banking cards need to be replaced by smart card enabled cards, already gaining momentum, the Turkish market presents potential significance (Gemplus, 2003). There are already 40 million payment cards in circulation in Turkey. With 75 million consumers, the Turkish market presents substantial opportunities.

The market in Turkey offers other opportunities. A critical driver for smart card conversion is the inclusion of differentiating services through multi-application cards. The EMV migration project by Garanti Bankasi in Turkey, which has implemented a co-branded debit / credit smart card with a loyalty scheme involving an estimated 100 retail partners, indicates the significance of results that can be achieved with the cards in Turkey (Cartes, 2003).

One issue not adequately addressed is the need for standardization to enable future interoperability between countries in regions like the European Union and Southeast Asia (Cartes, 2003). Turkey in its geographical location will however be a reliable bridge for that issue, implementing the EMV standards at the same time as Europe.

Smart cards have become an aspect of daily life not only in Europe but further in Asia. In the United States, the cards have been a solution in search of a problem. As of 2001, there were over one billion cards in circulation. The number is forecasted to increase $20 \%$ in the coming five years (Robinson, 2001). The smart cards are currently expensive in the United States for universal adoption, but the forced differentiation of debit cards from credit cards, the consequent reissue coupled with merchant plays, and continued pressure on interchange may encourage enough proliferation to achieve critical mass (Mercator Advisory Group, 2003).

In 2005 there is a shift in liability for fraudulent transactions in Europe. If a point-of-sale terminal is not upgraded to chip and pin, the retailer will be liable for loss through fraudulent transactions that might have been prevented if it had been compliant functionally. This contrasts with previous scenarios where the card issuer is liable for loss (Ciaran, 2004). With cards in Europe in 2005 and increases in Asia, and also in South America, the United States may be impacted by "fraud tourism", where card intruders move their operations to regions where chip and Pin are not compulsory. Even though transactions are authorized real time in the United States, magnetic stripes are simply not as secure as smart cards.

To analyze the effectiveness of smart cards in Turkey, the study will examine the following key institutions as leaders in smart card technology: Akbank, Deniz Bank, Garanti Bankasi, and Tekstil Bank.

The assets of these institutions are listed in Table 4 (Akbank, Deniz Bank, Garanti Bankasi and Tekstil Bank, 2005). 
Table 4: Financial Condition of Financial Industry in Turkey June 2004

(Liras in millions)

\begin{tabular}{|c|c|c|c|c|c|c|}
\hline Bank & Currency & Liquid Assets & Loans & $\begin{array}{c}\text { Permanent } \\
\text { Assets }\end{array}$ & Other Assets & Total Assets \\
\hline \multirow{3}{*}{ Akbank } & Liras & 5.111 & 3.722 & 559 & 714 & 10.105 \\
\hline & Exchange & 6.852 & 3.407 & 136 & 246 & 10.640 \\
\hline & Total & 11.963 & 7.129 & 695 & 960 & 20.745 \\
\hline \multirow{3}{*}{ Deniz Bank } & Liras & 1.022 & 795 & 191 & 72 & 2.080 \\
\hline & Exchange & 1.195 & 662 & 29 & 28 & 1.914 \\
\hline & Total & 2.217 & 1.457 & 220 & 100 & 3.994 \\
\hline \multirow{3}{*}{$\begin{array}{l}\text { Garanti } \\
\text { Bankasi }\end{array}$} & Liras & 2.661 & 2.723 & 1.804 & 370 & 7.558 \\
\hline & Exchange & 5.177 & 3.685 & 200 & 257 & 9.319 \\
\hline & Total & 7.838 & 6.408 & 2.004 & 627 & 16.877 \\
\hline \multirow{3}{*}{ Tekstil Bank } & Liras & 92 & 252 & 53 & 51 & 448 \\
\hline & Exchange & 181 & 135 & 6 & 2 & 324 \\
\hline & Total & 273 & 387 & 59 & 53 & 772 \\
\hline
\end{tabular}

These institutions have been the first in chip credit cards in Turkey and include Artan Kart, Axess, Bonus Card, and +Bonus Card smart cards. Bonus Card is the first multi-branded chip credit card in Turkey having installment and cash back reward. Axess is actually the fastest increasing credit card brand in Europe, having a million holders in nine months in 2002.

\section{EFFECTIVENESS OF SMART CARDS IN FINANCIAL INDUSTRY IN TURKEY}

The effectiveness of smart cards in the financial industry in Turkey is examined in business factors and technological factors introduced in industry literature. The business factors include budgeting, culture, customization, and loyalty. The technological factors include infrastructure, multi-functionality, payment speed and security of transaction. The technological factors are listed in Table 6, and the business factors are listed in Table 5. Though effectiveness factors are introduced from literature, indicated in the tables, the experience of a senior business analyst and key technology business managers of the examined institutions will further indicate initial adequacy of the factors for this study.

Table 5: Business Factors in Financial Industry

\begin{tabular}{|l|l|l|}
\hline $\begin{array}{l}\text { Budgeting Concerns for } \\
\text { On-line Transactions }\end{array}$ & $\begin{array}{l}\text { Costs of on-line authorization, processing and transaction are considerable in } \\
\text { smart card technology. }\end{array}$ & Wharton, 2002 \\
\hline Culture & $\begin{array}{l}\text { Cultural issues in a foreign country are as important as logistical and technical } \\
\text { issues in the favorable introduction of smart card technology. }\end{array}$ & Dent, 1999 \\
\hline Customization & $\begin{array}{l}\text { Customization in personalized marketing, sales and service is important in smart } \\
\text { card technology. }\end{array}$ & Dent, 1999 \\
\hline Loyalty & $\begin{array}{l}\text { Loyalty of profitable and retained customers is important in justifiable } \\
\text { investment in smart card technology. }\end{array}$ & $\begin{array}{l}\text { Kuschill, } \\
2002\end{array}$ \\
\hline
\end{tabular}


Table 6: Technological Factors in Financial Industry

\begin{tabular}{|l|l|l|}
\hline Multi-Functionality & $\begin{array}{l}\text { Multi-functional processing of diverse and numerous services and sources are } \\
\text { important in smart card technology. }\end{array}$ & $\begin{array}{l}\text { Whinston / } \\
\text { Choi, } 1998\end{array}$ \\
\hline Payment Speed & Speed is a convenient and important function of smart card technology. & Hirst, 2004 \\
\hline Security & $\begin{array}{l}\text { Security is crucial in the confidence of customers transacting in smart card } \\
\text { technology. }\end{array}$ & Hirst, 2004 \\
\hline $\begin{array}{l}\text { Technical } \\
\text { Infrastructure }\end{array}$ & $\begin{array}{l}\text { Seamless technology is an expensive but important investment in new smart card } \\
\text { technology. }\end{array}$ & $\begin{array}{l}\text { Briney, } \\
2002\end{array}$ \\
\hline
\end{tabular}

\section{FOCUS OF STUDY}

The focus of the study is to examine the importance of the aforementioned effectiveness factors in the implementation of smart card technology in Turkey. Though investment in this technology continues in other industries, examination in the current improvement in the financial industry enables potentially expandable implications of the factors. The study examines Akbank, Deniz Bank, Garanti Bankasi and Tekstil Bank, as the highest transaction smart card leaders in Turkey. The study is intended to assist both foreign and domestic entrants to the Turkish financial industry, in taking advantage of this technology. This study is timely.

\section{RESEARCH METHODOLOGY}

The research methodology of the study examines in a small sample the technological and business factors determined to be effective in the implementation of smart card technology in the financial industry in Turkey, in two iterative stages of analysis.

In stage 1 an exploratory survey was conducted of three domestic banks, Akbank, Deniz Bank and Garanti Bankasi, leaders in smart cards, to analyze the effectiveness of the factors in Tables 5 and 6 . A key technology business manager and his staff in each of the banks evaluated the factors. Their evaluation was from a six-point perception rating scale of 5-very high importance, 4- high importance, 3-intermediate importance, 2- low importance, 1- very low importance, to 0- no importance, in effectiveness of the factors in implementation of their smart card technology.

In stage 2 an initial case study was conducted of the fourth bank, Tekstil Bank, to further analyze the effectiveness factors. A key senior business analyst in the bank, having in-depth experience in point-of-sale processes and technologies of 15 years, and his staff, evaluated the factors in interviews with one of the authors. His evaluation, in a summary of the interviews, was from the rating scale introduced in stage 1.

The results from stages 2 and 1 were then analyzed, compared and averaged by the authors of the study.

\section{SURVEY OF AKBANK, DENIZ BANK AND GARANTI BANKASI}

The survey of Akbank, Deniz Bank and Garanti Bankasi in stage 1 disclosed higher importance in technological factors than in business factors, as indicated in Table 7.

Table 7: Analysis of Summary Effectiveness Factors of Survey

\begin{tabular}{|l|c|c|}
\hline Summary Factors & Mean & Standard Deviation \\
\hline Business & 3.00 & 1.35 \\
\hline Technological & 3.17 & 1.53 \\
\hline
\end{tabular}


From the results of the survey, payment transaction speed $(\mathrm{m}=2.00)$ and infrastructure $(2.67)$ were disclosed as less important, while security (4.00) and multi-functionality (4.00) were disclosed as more important, in technological factors. Budgeting (2.00) and customization (2.33) was disclosed as less important, while loyalty (4.67) and culture (3.00) were indicated as more important, in business factors. The results are indicated in Table 8.

Table 8: Analysis of Detailed Effectiveness Factors of Survey

\begin{tabular}{|l|c|c|}
\hline Detailed Factors & Mean & Standard Deviation \\
\hline Budgeting Concerns & 2.00 & 1.73 \\
\hline Culture & 3.00 & 0.00 \\
\hline Customization & 2.33 & 0.58 \\
\hline Loyalty & 4.67 & 0.58 \\
\hline Multi-Functionality & 4.00 & 1.00 \\
\hline Payment Speed & 2.00 & 2.00 \\
\hline Security & 4.00 & 1.00 \\
\hline Technical Infrastructure & 2.67 & 1.53 \\
\hline
\end{tabular}

\section{CASE STUDY OF TEKSTIL BANK}

The case study of Tekstil Bank in stage 2, in contrast to the results of the survey of Akbank, Deniz Bank and Garanti Bankasi, disclosed higher importance in business factors than in technological factors, but not significantly higher importance, as indicated in Table 9.

Table 9: Analysis of Summary Effectiveness Factors of Case Study

\begin{tabular}{|l|c|}
\hline Summary Factors & Score \\
\hline Business & 3.50 \\
\hline Technological & 3.25 \\
\hline
\end{tabular}

From the results of the case study, infrastructure (2.00) and multi-functionality (3.00) was disclosed to be less important, while speed (4.00) and security (4.00) were disclosed to be more important, in technological factors. Budgeting (3.00), culture (3.00), and customization (3.00) were disclosed to be less important, while loyalty was distinguished and indicated as more important (5.00), in business factors. These results are indicated in Table 10.

Table 10: Analysis of Detailed Effectiveness Factors of Case Study

\begin{tabular}{|l|c|}
\hline Detailed Factors & Score \\
\hline Budgeting Concerns & 3.00 \\
\hline Culture & 3.00 \\
\hline Customization & 3.00 \\
\hline Loyalty & 5.00 \\
\hline Multi-Functionality & 3.00 \\
\hline Payment Speed & 4.00 \\
\hline Security & 4.00 \\
\hline Technical Infrastructure & 2.00 \\
\hline
\end{tabular}




\section{SUMMARY ANALYSIS OF SURVEY AND CASE STUDY}

The results of the case study and the survey disclosed essential equivalency in the importance of business factors and technological factors, in the implementation of smart card technologies in financial Turkish institutions. However, loyalty, security of transactions and multi-functionality were higher, payment speed and culture were intermediate, and customization, budgeting and infrastructure of technology were lower, in importance. The distinction in the initial study of technological and business factors in summary is less important than the detailed factors, such that further individual reviews of the specific factors in these institutions may be fruitful in future studies.

Table 11: Analysis of Effectiveness Factors of Survey and Case Study - Summary

\begin{tabular}{|l|c|c|}
\hline Detailed Factors & Survey Mean & Case Study Score \\
\hline Budgeting Concerns & 2.00 & 3.00 \\
\hline Culture & 3.00 & 3.00 \\
\hline Customization & 2.33 & 3.00 \\
\hline Loyalty & 4.67 & 5.00 \\
\hline Multi-Functionality & 4.00 & 3.00 \\
\hline Payment Speed & 2.00 & 4.00 \\
\hline Security & 4.00 & 4.00 \\
\hline Technical Infrastructure & 2.67 & 2.00 \\
\hline
\end{tabular}

\section{PRELIMINARY IMPLICATIONS OF STUDY}

An implication of this initial study is the clear importance of the security technological factor in the implementation of smart cards. These cards are increasing in Turkey and in other countries. Banks and private card institutions and also retailers are shifting and upgrading to smart card technology. Security is key in the integrity of card functionality and customer trust. New studies disclosing that revenues in this market reached $\$ 453.3$ million in 2003 and are forecasted to reach $\$ 1196.3$ million in 2008 (Frost \& Sullivan, 2004) indicate the importance of security of this technology.

Another implication is the demonstrated importance of the loyalty business factor. Loyalty applications, such as loyalty point programs and rewards on smart cards, are including diverse information on customers, that is enabling financial institutions in Turkey to better market products and services to highly profitable customers. These applications are key in the justification of smart card technologies. The institutions learn habits and inclinations about their customers (Hitachi, 2002), that facilitate further loyalty in personalized and tailored marketing and sales. This information is potentially translatable to improved revenue and profitability.

A final implication is the importance of the multi-functionality technological factor. Smart cards are flexibly integrating multiple applications in non-financial fields in Turkey, as in education, entertainment, medicine, shopping, and travel. Such multiple applications however require the interface to the smart card systems to be simple. Customers have to have smart card functionality in transacting in multiple scenarios. Lastly, not like traditional credit and identification cards, smart cards empower customers to include personalized and selected applications through the increasing power of the Internet (Datacard, 2004).

\section{LIMITATIONS AND OPPORTUNITIES IN RESEARCH}

The study furnishes a framework for further researching effectiveness factors in smart card technologies in Turkey. The implications of the study of one specific industry and of a small subject sample cannot be generalized and have to be filtered and interpreted cautiously. Research with a larger sample of industries, institutions and technology business professionals is needed in future studies. 


\section{CONCLUSION}

This study of smart card technology in Turkey is significant in initial findings. Entrants to Turkey will be assisted in learning the importance of technological and business factors introduced in the study. Initiatives of Turkey in joining the European Union will be helped by the indication of innovation in smart card technologies that is characteristic of a $21^{\text {st }}$ century country.

\section{REFERENCES}

1. $\quad$ Alliance. (2004). New Smart Card Alliance Report. Industry News, November 12.

2. Alliance. (2003). Schlumberger Releases Annual Smart Card Market Analysis: Momentum Returning with Key Developments in Mobile Communications, Banking and Public Sector Markets. Industry News, April 28.

3. Alto, P. (2004). Smart Card Adoption Accelerated by EMV Migration and Increasing Occurrences of Fraud. Frost \& Sullivan, November 4.

4. Briney, A. (2002). A Smart Card for Everyone? Information Security, March 2002.

5. $\quad$ Cartes. (2003). Cartes 2003 Exhibitors. Cartes \& IT Security, February/March 2003.

6. Chan, Siu-cheung C. (1999). An Overview of Smart Card Security.

7. $\quad$ Ciaran, R. (2004). Smart Cards: The Chip and Pin Revolution. PDFM Publishers, September 24.

8. Datacard. (2004). Implementing Multi-Application Smart Cards, Datacard.

9. Dent, E. (1999). Technology Clients and Psychology: The Case of Smart Cards. University of Maryland University College, March 1999.

10. Feld, L. (2004). Country Analysis Briefs. EIA, May 2004.

11. Frost \& Sullivan. (2004). Smart Card Adoption Accelerated by EMV Migration and Increasing Occurrences of Fraud, Nov 2004.

12. Gemplus. (2003). Gemplus Partners with Universal Kart for EMV Card Personalization in Turkey.

13. Gilhooly, K. (2001). Biometrics: Beyond Smart Cards. Computerworld, May 17.

14. Hirst, C. (2004). Market Focus: Contactless Chip Cards Worldwide: 2003-2008. Gartner Group, May 2004.

15. http://usa.visa.com/about_visa/about_visa_usa/history.html/2004.

16. http://www.akbank.com.tr/en/serv_en.asp?page=928\&mcat=927/2005.

17. http://www.garantibank.com/banking/credit_cards.html/2005.

18. http://www.hitachi.co.jp/Div/smartcard/english/applications/point_top_e.html/2002.

19. Kuschill, J. (2002). Is The Emperor Wearing Any Clothes? Colloquy, March.

20. Mercator Advisory Group. (2003). Micro-Payments Get Smart: On-Line Debit \& Chip - A Winning Combination.

21. Petersburg, C., Yen, D, Binshan, L., and David, C. (2002). Smart Cards in the Internet Commerce Era. The Haworth Press Online Catalog.

22. Robinson, B. (2001). Is It Too Late for Smart Cards? Information Week, March 29.

23. Smart Card Group. (2002). House of Cards.

24. Turkish Bank Association. (2004). Turkish Banking System. Banks Association of Turkey.

25. Thomson, C. (2004). Smart Cards Boost Value Of Global Card Market. Card Technology, October 22.

26. Townsend, R. (2003). Finance: History, Development \& Market Overview. Banking and Stock Exchange, Embassy of Turkey.

27. Wharton, K. (2002). New Payment Methods Give Old Fashioned Checks and Credit Cards a Run for Their Money. Techtarget, January 23.

28. Whinston, A. and Choi, S. (1998). Enabling Smart Commerce in the Digital Age. KPMG, May.

29. Yapi, Kredi Bankasi (2004). 2005 Macroeconomic Forecasts for the Turkish Economy. Economic Research, October 13. 


\section{NOTES}

